\title{
Economic growth and tariff levels in the United States: A Granger casality analysis
}

\author{
Hyung Min Kim \\ Department of Political Science, Myongii University \\ Republic of Korea \\ bmkim@mju.ac.kr
}

Abstract. The objective of this research is to investigate the causal relationship between economic growth and tariff levels (i.e., levels of trade protection) in the United States. This research empirically examines the relationship between trade protectionism and economic growth using US tariff levels and GDP growth data for the period of 1821-2017. By employing Granger causality analysis, this research finds that, for the United States, GDP growth unidirectionally affects nominal tariff levels over the short term. Generalizing the results, this research provides empirical evidence that economic growth influences the level of trade protection in the United States. Economic conditions, at least in the United States, do in fact affect its trade policies, though US trade policies for either protectionism or liberalization have little impact on the nation's economic performance (one-way causation from economic growth to trade protectionism in the US). Lastly, this research provides important theoretical and policy implications regarding hegemonic stability theory and recent economic conflicts over tariffs (in March/April 2018 and thereafter) of the United States with China and the European Union.

Keywords: economic growth, Granger causality, protectionism, tariff level, US economics.

JEL Classification: A10, B40, F10, O10

\section{INTRODUCTION}

Do a state's economic conditions (prosperity or depression) affect its trade policies? And do those trade policies (trade liberalization or protectionism) affect its economic growth? The purpose of this study is to empirically examine the causal relationship between economic growth and tariff levels (or levels of trade protection) in the United States. Previous theoretical and empirical research on topic such as Strange (1979) has posited that tariff policies are heavily influenced by productive capacity. McKeown (1984) also argues that tariff levels and economic growth tend to move in opposite directions, and that histories of commercial policies illustrate the relations between prosperity and free trade, or protectionism and depression. This empirical research examines theoretical arguments on this topic, by analyzing the 
relationship between economic growth and trade protection using US tariff levels and GDP growth data for the period of 1821-2017. More specifically, this research seeks to answer several research questions: what is the causal relationship between tariff levels (or, more generally, levels of trade protection) and economic growth in the US; and do low (or high) tariff levels cause economic growth, or does economic growth cause low (or high) tariff levels in the US? Investigating this set of research questions will provide important policy and theoretical implications for international political economy; not only for theoretical arguments such as hegemonic stability theory but also for recent economic conflicts over tariffs (in March/April 2018 and thereafter) of the United States with China and the European Union.

Using a Granger causality analysis (Granger, 1969, 1980; Freeman, 1983), this research finds that, for the period of 1821-2017, GDP growth in the United States affected tariff levels over the short term, but that tariff levels did not affect GDP growth over either the short or long term. In other words, Granger causality analysis provides empirical evidence that US trade policies are influenced by the United States' economic performance (free trade in prosperity, protectionism in depression), as McKeown (1984) argues. It also provides evidence that a state's economic performance is not directly affected by its trade policies, at least in the US. The remainder of this research falls into three sections. The first section explores the causal mechanisms of the relationship between tariff levels and economic growth, with a focus on previous theoretical and empirical studies. The second section describes the data, measurement of variables, and statistical method used to test the main hypotheses in this research. This paper then presents the empirical results with a focus on its implications. The final section summarizes the core findings, suggests directions for future research (focusing on expanding the scope of the analysis), and provides theoretical and policy implications derived from the empirical results.

\section{LITERATURE REVIEW AND DERIVATION OF THESES}

Previous research on the topic argues that a state's trade policies (either protectionism or liberalization) are closely related with its economic performance. ${ }^{1}$ For example, McKeown (1984) proposes utility-maximizing theory and satisfying theory to explain the openness of a trading system and the level of international prosperity. McKeown (1984) provides empirical evidence that, during 1854-1914, tariff increases were related to either low growth rates in Germany or downswing business cycles in the US. Trade protectionism, which is suggested by high tariff levels, was negatively related to macroeconomic performance. ${ }^{2}$ Conybeare (1983) identifies several determinants of tariff levels in developed and developing countries: the nature of the international system, the level of economic development, intragovernmental power and bargaining, and the influence of nongovernmental interest groups. According to Conybeare (1983), conventional economic history suggests that tariff levels are primarily a function of a country's level of economic development (p. 450; see also Maizels, 1963). However, there might be a reciprocal causation. Rapid economic development requires the promotion of manufacturing industries via tariff protection; tariffs sometimes slow economic growth through the creation of coalitions to preserve inefficient industries (Conybeare, 1983, p. 450; see also Olson, 1982, pp. 118-145). Using the

\footnotetext{
${ }^{1}$ For example, economists explain national tariff levels via economic development or historical accidents such as interstate wars. See Kreuger (1974) for rent-seeking theories on this topic; Pincus (1975) for pre-Civil War US tariffs analysis; Caves (1976) for the analysis of Canadian tariff structure; Anderson \& Baldwin (1986) for the analysis of tariff protection in industrial countries.

2 Similarly, Gustav Schmoller, the economist of the German historical school, argued that "The times of boom, of increasing exports, of new openings of overseas markets, are the natural free trade epochs, while the reverse is true in times of foreign slumps, of depressions, of crisis" (quoted in McKeown, 1984, p. 215; see also, Rosenberg, 1967).
} 
nominal tariff and GDP data in 1902 and 1971, Conybeare (1983)'s empirical analysis provides mixed results; in 1902, GDP growth had no effect on tariff levels; but, in 1971, GDP growth did have a negative effect on trade protectionism in both developed and developing countries.

Other scholars on the political economy of protection also argue for the causal relation between tariff levels and economic development. For example, Ray (1974) finds that, in both developed and developing countries, the levels of economic development explain cross-national tariff levels. Cassing et al. (1986) argue that tariff levels move in a cycle coupled with the business cycle and that tariff levels decline during periods of economic prosperity and rise during economic recessions (see also Strange, 1979). Crucini (1994) argues that monetary policies, influencing nominal prices and values of specific duties, have large effects on tariff levels, and empirically finds strong links among money, prices, and real tariff rates during 1900-1940 in the US. DeJong and Ripoll (2006) argue that the relationship between tariff levels and economic growth is contingent upon the level of development, ${ }^{3}$ and that it is only applicable to developed countries. Analyzing panel data of 60 countries for the period of 1975-2000, DeJong and Ripoll (2006) find that the relationship between tariff levels and economic growth is negative and significant in developed countries but positive and insignificant in developing countries.

Some economic theories are ambiguous, though, as to the relationship between trade policies and economic growth; protection can either reduce or increase growth rates (for theoretical research, see Grossman \& Helpman, 1991; Rivera-Batiz \& Romer, 1991; Stokey, 1991; Young, 1991). Some empirical research provides empirical evidence that free trade is associated with economic growth and trade protection slows growth (see Lee, 1993; Sachs \& Warner, 1995; Harrison, 1996; Taylor, 1998). Similarly, other empirical studies find evidence that openness is positively related to economic growth (see Bairoch, 1989; Dollar, 1992; Ben-David, 1993; Edwards, 1998; Frankel \& Romer, 1999; Wacziarg, 2001; Vamvakidis, 2002; Clemens \& Williamson, 2004; Wacziarg \& Welch, 2008). Yet, others doubt the causal influence of trade on economic growth (see Rodríguez \& Rodrik, 2000; Acemoglu et al., 2001; Yanikkaya, 2003; Schularick \& Solomou, 2011).4

Other researchers examine the relation between tariff levels and economic performance in the US. For example, Stern (1964) evaluates the economic significance of tariffs and import quotas in the US. Cheh (1974) finds that tariff levels are negatively related to growth rates in sectors covered by the tariff in the US. Lavergne and Shell (1983) provide information pertinent to the political economy of trade barriers in the US. Epstein and O'Halloran (1996) argue that political institutions play an important role in shaping US foreign trade policies, and find that, between 1877 and 1934, changes in aggregate economic conditions and unified partisan control of national government equally influenced tariff policies in the era from post-Reconstruction to $1934 .{ }^{5}$ Lavergne and Shell (1983) empirically explain how import duties affect trade protectionist policies in the US, focusing on theories of "pressure groups" versus theories of "principle behavior" of protection. Lavergne and Shell (1983) examine the institutional details of the US tariff-making processes, utilizing nominal and effective tariff levels as well as measures of nontariff barriers, and find that interest groups (pressure groups) and displacement cost considerations had no effect on the levels of changes in US tariffs since 1930; however, other determinants of trade policies, such as comparative disadvantages, import penetration, and international bargaining considerations, were.

${ }^{3}$ For similar theoretical arguments, see Lucas (1988); Grossman \& Helpman (1991); Young (1991); Matsuyama (1992).

${ }^{4}$ For other empirical research on this topic, see Capie (1983, 1994); Foreman-Peck (1995).

${ }^{5}$ For the effect of partisan policies on US protectionism, see Thompson (1888); Stanwood (1903); Taussig (1931); Baack \& Ray (1983); Brady (1988); Eichengreen (1989); Magee et al. (1989); Conybeare (1991); Stewart (1991); Iwrin (2001). 
Noting that, in the late nineteenth century, rapid economic growth in the US was coupled with high import tariffs, ${ }^{6}$ O'Rourke (2000) argues that, though there was a correlation between high tariffs and growth, trade protection was not a key factor behind US economic growth during the period; rather, productivity growth in non-trade sectors (such as utilities, distribution and other services) was. ${ }^{7}$

Other studies examine this topic in different countries and regions. For example, Riedel (1977) finds that industries with high growth rates experienced larger reductions of effective protection in West Germany. Mansfield and Busch (1995) argue that societal and statist approaches of trade policies (focusing on pressure groups and national interest/domestics institutions) are complementary rather than mutually exclusive. Examining cross-national patterns of nontariff barriers with data in 1983 and 1986 of fourteen developed countries, Mansfield and Busch (1995) find that factors emphasized by both approaches and their interaction are all related to cross-national patterns of nontariff barriers, and that tariffs are strongly related to the incidence of nontariff barriers (substitutes). Afontsev (1999) examines the tariff structure in post-communist Russia (1992-1997) focusing on endogenous protection theory, ${ }^{8}$ and finds that political economic forces played an important role in Russian trade protection policies. Lederman (2005), analyzing the case of Chile, explains why countries change their trade policies over the course of history (see also, Bairoch, 1972, 1976, Verdier, 1987, Meadwell, 2002 for an analysis of the case of France; Constantopoulos, 1974, Helleiner, 1977, Takacs, 1981, and Marvel \& Ray, 1983 for an analysis of North America and Western Europe; Isakova et al., 2016 for Belarus, Kazakhstan, and Russia).

\section{EMPIRICAL ANALYSIS}

\subsection{Data and measurement}

One source of data used in this research is the average nominal tariff rate for a national economy. As Lavergne and Shell (1983) argue, the average nominal rate is the best indicator of relative trade protectionism; however, the validity of this measurement might suffer from two problems: effective tariffs and the existence of non-tariff barriers. First, effective tariff levels take into account the possibility that nominal duties for a final product may differ from those applied to the inputs used in its manufacture; for most goods, effective rates are higher than nominal rates. However, Chen (1974) correctly argues that nominal tariffs are probably more relevant as measures of trade protectionism; first, in trade negotiations, the concept of effective tariffs is virtually absent; second, in practice, it is easier for pressure groups to seek changes in their own nominal rates than in the rates of all production inputs; lastly, effective tariffs are difficult to compute and have limited practical meaning. Next, the available evidence indicates that the significance of non-tariff barriers (e.g., import quotas, voluntary export restraints, restrictive licensing, discriminatory governmental procurement, anti-dumping and countervailing procedures, and escape clauses) increased in the 1970s and '80s, which in turn affected an increasing portion of the trade volumes in industrialized countries. However, like effective tariffs, data on non-tariff trade barriers are hard to obtain and often unreliable. For these reasons, this research uses the average nominal tariff levels to measure the levels of trade protection in the US; this research uses the USITC Tariff database (US

\footnotetext{
6 This historical observation is also shared by Bairoch (1993); Batra (1993); Fallows (1994); Eckes (1995); Irwin (1998, 2001).

${ }^{7}$ For other related researches, see Corden (1974); Ray (1981a, 1981b); Baldwin (1982, 1985); Gardner \& Kimbrough (1989); Hansen (1990); Trefler (1993); Bayward \& Elliott (1994); Olarreaga \& Soloaga (1998).

8 Trade policies are implemented by interactions among voters, pressure groups, and politicians and bureaucrats; for endogenous protection theory, see Mayer (1984); Nelson (1988); Hillman (1989).
} 
International Trade Commission, 2018) to measure this variable of Nominal Tariff Level. ${ }^{9}$ The data on another variable, GDP Growth Rate, are collected from the MeasuringWorth Project database (Johnston \& Williamson, 2018). ${ }^{10}$

\subsection{Estimation method}

The estimation method used in this research is Granger causality analysis (or Wiener-Granger causality analysis, see Wiener, 1956; Granger 1969, 1980; see also Freeman, 1983; Gujarati \& Porter, 2009). ${ }^{11}$ The reasons and objectives of this analysis are well argued by Granger (1969) himself: on some occasions, there is a difficulty in deciding the direction of two research variables (p. 424). ${ }^{12}$ As traditional regression analysis examines the dependences of one variable on others, this dependence does not imply causation (Gujarati \& Porter, 2009, p. 652). For example, in our research, there are a few possible causal scenarios regarding GDP growth and tariff levels in the US: first, the GDP growth causes tariff levels; second, tariff levels cause GDP growth; third, there is a reciprocal causation between GDP growth and tariff levels; and, lastly, there is no causal relationship between GDP growth and tariff levels (independence). Using the Granger causality analysis provides empirical evidence as to which causal scenario is the real case in the relationship between GDP growth and tariff levels. In other words, Granger causality analysis is utilized in this research to examine the existence and direction of causal relationship between GDP growth and tariff levels in the US.

Application of the Granger causality test involves estimating the following two regressions:

Nominal Tariff Level, ${ }_{t}=\sum \alpha_{i} *$ GDP Growth Rate, $t_{t-i}+\sum \beta_{j} *$ Nominal Tariff Level, $t_{-j}+\mathrm{u}_{1 t}$ (Equation1) GDP Growth Rate, $t_{t}=\sum \lambda_{i} *$ GDP Growth Rate, $t-i+\sum \delta_{j} *$ Nominal Tariff Level, ${ }_{t-j}+\mathrm{u}_{2 t} \quad$ (Equation2)

Depending on the results of these two regressions, there are four different causal scenarios between GDP growth and tariff levels in the US (see also, Gujarati \& Porter, 2009, pp. 652-658):

1) Unidirectional causality from GDP growth to tariff levels: if the estimated coefficients on the lagged GDP Growth Rate in Eq. (1) is statistically different from zero as a group (i.e., $\sum \alpha_{i} \neq 0$ ) and the set of estimated coefficients on the lagged Nominal Tariff Level in Eq. (2) is not statistically different from zero as a group (i.e., $\sum \delta_{j}=0$ ).

2) Unidirectional causality from tariff levels to GDP growth: if the set of estimated coefficients on the lagged GDP Growth Rate in Eq. (1) is not statistically different from zero as a group (i.e., $\sum \alpha_{i}=0$ )

\footnotetext{
9 To check the reliability of the database used to measure the Nominal Tariff Level variable, data provided by other sources are also examined: US Census Bureau Historical Statistics of the United States (diverse years) and Statistical Abstract of United States (diverse years), and others such as UNCTAD (United Nations Conference on Trade and Development) TRAINS (Trade Analysis Information System) database (UNCTAD, 2018) and WTO (World Trade Organization) Trade and Tariff database (WTO, 2018).

10 To check the reliability of the dataset used to measure the GDP Growth Rate variable, data provided by other sources are also examined: Penn World Tables 9.0 (Feenstra et al., 2015), Maddison Project database (Bolt \& Zanden, 2014; Bolt et al., 2018), IMF (International Monetary Fund) International Financial Statistics (diverse years), and World Bank's World Development Indicators (diverse years).

${ }^{11}$ For related estimation methods, such as distributed lag analysis, autoregressive distributed lag analysis, and vector autoregressive model analysis, and some of their applications in international studies, see Sims (1980a, 1980b); Engle \& Granger (1987); Freeman et al. (1989); Phillips \& Hansen (1990); Johansen (1991); Phillips (1991); Phillips \& Loretan (1991); Pesaran \& Shin (1998); Thompson \& Reuveny (1998); Crescenzi \& Enterline (1999); Pesaran et al. (2001); Hood et al. (2008).

${ }^{12}$ For discussions on the direction of causality, see Brunner \& Meltzer (1979); Zellner (1979).
} 
and the set of estimated coefficients on the lagged Nominal Tariff Level in Eq. (2) is statistically different from zero as a group (i.e., $\sum \delta_{j} \neq 0$ ).

3) Feedback, or bilateral causality: if the sets of estimated coefficients on GDP Growth Rate and Nominal Tariff Level are statistically different from zero in both equations.

4) Independence: if the sets of estimated coefficients on GDP Growth Rate and Nominal Tariff Level are not statistically different from zero in both equations.

\section{RESULTS AND DISCUSSION}

Tables 1 and 2 present the statistical results for the period of 1821-2017. Table 1 provides the results for Granger causality analysis of US tariff levels and GDP growth. Table 2 shows the results for unrestricted regression analysis of US tariff levels on GDP growth and of GDP growth on tariff levels.

First, Table 1 displays the results regarding Granger causality analysis. ${ }^{13}$ Before considering Granger causality analysis, different unit-root tests were performed to see whether time-series variables of Tariff and GDP Growth were generated by a stationary process. The results indicate that, utilizing ADF (augmented Dickey-Fuller test, Dickey \& Fuller, 1979) and PP (Phillips-Perron test, Phillips \& Perron, 1988), ${ }^{14}$ the null hypotheses of two variables (Nominal Tariff Level and GDP Growth) containing a unit root could be rejected (otherwise, the research should use first differencing of Nominal Tariff Level and GDP Growth Rate variables, see Maddala, 2001). Granger causality analysis (in Table 1) provides clear empirical evidence that, in the US, GDP growth unidirectionally influences tariff levels over the short term. Specifically, the results show that, in the short term, the GDP growth Granger-causes the nominal tariff levels. With three lagged terms of the Nominal Tariff Level variable, the estimated F-value and (asymptotic) chisquare value indicate a statistical significance at the conventional level ( $F$-value 2.20, P-value 0.089; chisquare value 6.85, $\mathrm{P}$-value 0.077$)$. The estimated chi-square value with four lagged terms also indicates a statistical significance (chi-square value 7.89, P-value 0.096). However, the results also indicate that with longer terms (e.g., those with more than four lagged terms), the GDP growth does not Granger-cause the nominal tariff levels in the US. Finally, the analysis of the effect of tariff levels on economic growth provides no empirical evidence of tariff levels affecting GDP growth. In the short and long term of the GDP Growth Rate variable, the nominal tariff levels do not Granger-cause GDP growth in the US.15

\footnotetext{
13 Gujarati \& Poter (2009) argue for the importance of lagged terms for the Granger causality test: "the number of lagged terms to be included in regressions is an important practical question," and that "the direction of causality may depend critically on the number of lagged terms included" (p. 655, emphasis original). Since there is no clear theoretical argument for lagged terms analyzed for the relationship of tariff levels and economic growth, this study performed its own analyses utilizing different lag terms (based on Akaike information criterion (AIC), Akaike, 1973; Schwarz Bayesian information criterion (BIC), Schwarz, 1978, Raftery, 1995; Newey-West bandwidth (NWB), Newey \& West, 1994) to see whether the results hold across different sets of lagged terms.

14 The Phillips-Perron test is a modification of the Dickey-Fuller test of correcting for any serial correlation and heteroskedasticity in the errors.

15 To check the robustness of the results, this research also performed a series of sensitivity analyses, for example, using different lagged terms, by sub-sampling different time periods (during/beyond inter-war period (1918-1939 and otherwise), pre- and post-WWII period (before and after 1945), during/beyond the Cold War period (19451989/1991 and otherwise), during/beyond the GATT/WTO period (before and after 1947/1995)), and other alternatives. The results are generally in line with those from this research. All analyses were performed in this research using Stata 15.0. All the results and Stata do and log files are available from the author upon request.
} 
Table 1

Granger Causality Analysis for Tariff Levels and GDP Growth, the United States, 1821-2017

\begin{tabular}{|c|c|c|c|c|c|c|c|c|}
\hline \multirow{3}{*}{$\begin{array}{c}\text { \# of } \\
\text { Lags } \\
1\end{array}$} & \multicolumn{8}{|c|}{ GDP does not Granger cause tariff } \\
\hline & \multicolumn{2}{|c|}{ F-value } & \multicolumn{2}{|c|}{$\begin{array}{l}\text { chi }^{2} \text {-value } \\
\text { (asymptotic) }\end{array}$} & \multicolumn{2}{|c|}{$\begin{array}{l}\text { ADF unit-root } \\
\text { test statistic }\end{array}$} & \multicolumn{2}{|c|}{$\begin{array}{l}\text { PP unit-root } \\
\text { test statistic }\end{array}$} \\
\hline & 1.07 & $(0.303)$ & 1.08 & $(0.298)$ & $-3.19 *$ & $(0.087)$ & -3.11 & $(0.104)$ \\
\hline 2 & 1.02 & $(0.363)$ & 2.09 & $(0.351)$ & $-4.13 * * *$ & $(0.006)$ & $-3.32^{*}$ & $(0.063)$ \\
\hline 3 & $2.20^{*}$ & $(0.089)$ & $6.85 *$ & $(0.077)$ & $-4.90 * * *$ & $(0.0003)$ & $-3.50 * *$ & $(0.040)$ \\
\hline 4 & 1.88 & $(0.116)$ & $7.89 *$ & $(0.096)$ & $-4.47 * * *$ & $(0.002)$ & $-3.57 * *$ & $(0.032)$ \\
\hline 5 & 1.64 & $(0.152)$ & 8.69 & $(0.122)$ & $-3.73 * *$ & $(0.020)$ & $-3.58^{* *}$ & $(0.031)$ \\
\hline 6 & 1.51 & $(0.178)$ & 9.71 & $(0.137)$ & $-5.02 * * *$ & $(0.0002)$ & $-3.61 * *$ & $(0.029)$ \\
\hline 7 & 1.47 & $(0.181)$ & 11.17 & $(0.132)$ & $-3.95 * * *$ & $(0.010)$ & $-3.58 * *$ & $(0.032)$ \\
\hline \multirow[t]{2}{*}{8} & 1.02 & $(0.425)$ & 8.94 & $(0.347)$ & $-3.92 * *$ & $(0.011)$ & $-3.51 * *$ & $(0.038)$ \\
\hline & \multicolumn{8}{|c|}{ The tariff does not Granger cause GDP } \\
\hline 1 & 1.38 & $(0.241)$ & 1.40 & $(0.236)$ & $-7.87 * * *$ & $(0.0000)$ & $-8.65^{* * *}$ & $(0.0000)$ \\
\hline 2 & 1.16 & $(0.316)$ & 2.38 & $(0.304)$ & $-7.90^{* * *}$ & $(0.0000)$ & $-8.68^{* * *}$ & $(0.0000)$ \\
\hline 3 & 0.77 & $(0.514)$ & 2.39 & $(0.496)$ & $-7.59 * * *$ & $(0.0000)$ & $-8.59 * * *$ & $(0.0000)$ \\
\hline 4 & 0.84 & $(0.502)$ & 3.52 & $(0.475)$ & $-6.03 * * *$ & $(0.0000)$ & $-8.40^{* * *}$ & $(0.0000)$ \\
\hline 5 & 1.22 & $(0.301)$ & 6.48 & $(0.263)$ & $-5.30 * * *$ & $(0.0000)$ & $-8.25^{* * *}$ & $(0.0000)$ \\
\hline 6 & 1.02 & $(0.413)$ & 6.58 & $(0.362)$ & $-4.80 * * *$ & $(0.0001)$ & $-8.17 * * *$ & $(0.0000)$ \\
\hline 7 & 0.94 & $(0.481)$ & 7.11 & $(0.418)$ & $-4.61 * * *$ & $(0.0001)$ & $-8.13 * * *$ & $(0.0000)$ \\
\hline 8 & 0.79 & (0.615) & 6.92 & $(0.546)$ & $-4.40 * * *$ & $(0.0003)$ & $-8.13^{* * *}$ & (0.0000) \\
\hline
\end{tabular}

Notes: The upper-half includes unit-root test results for Nominal Tariff Level variable, and the lower-half includes those for GDP Growth variable. P-values appear in parentheses next to F-value, chi-squared value, and unit-root test statistic. ${ }^{*} \mathrm{p} \leqq .10,{ }^{*} \mathrm{p} \leqq .05, * * * \mathrm{p} \leqq .01$.

Source: own evaluation.

Table 2 shows the results of the unrestricted regression analysis for tariff levels and GDP growth, providing empirical evidence in line with our Granger causality analysis. The GDP growth causes the nominal tariff levels, in the short term. The estimated coefficient for GDP Growth of the first lagged term is negative (-0.045) and statistically significant at the conventional level (P-value 0.094); that for GDP Growth of the third lagged term is positive (0.063) and statistically significant ( $P$-value 0.034$)$. Lastly, the results also indicate that there is no empirical evidence of GDP growth affecting tariff levels for the longer term or of tariff levels affecting GDP growth for either the short or long term in the US. All in all, the empirical results indicate that, for the period of 1821-2017, United States' economic conditions affected its trade policies in the short term (the short-term unidirectional effect of US economic growth on its tariff levels). 
Table 2

Unrestricted Regression Analysis for Tariff Levels and GDP Growth, the United States, 1821-2017

\begin{tabular}{|c|c|c|c|c|c|c|c|}
\hline $\begin{array}{l}\text { Dep. } \\
\text { Var. }\end{array}$ & $\begin{array}{l}\text { Ind. } \\
\text { Var. }\end{array}$ & Coefficient & P-value & $\begin{array}{l}\text { Dep. } \\
\text { Var. }\end{array}$ & $\begin{array}{l}\text { Ind. } \\
\text { Var. }\end{array}$ & Coefficient & P-value \\
\hline \multirow{17}{*}{$\begin{array}{l}\text { Tariff } \\
\text { Level }\end{array}$} & Tariff Lag1 & $1.161 * * *(0.074)$ & 0.000 & \multirow{17}{*}{$\begin{array}{c}\text { GDP } \\
\text { Growth }\end{array}$} & GDP Lag1 & $0.461 * * *(0.076)$ & 0.000 \\
\hline & Tariff Lag2 & $0.045(0.109)$ & 0.677 & & GDP Lag2 & $0.008(0.084)$ & 0.920 \\
\hline & Tariff Lag3 & $-0.172^{*}(0.103)$ & 0.097 & & GDP Lag3 & $-0.095(0.084)$ & 0.260 \\
\hline & Tariff Lag4 & $-0.261 * *(0.104)$ & 0.013 & & GDP Lag4 & $-0.164^{*}(0.085)$ & 0.054 \\
\hline & Tariff Lag5 & $0.139(0.104)$ & 0.182 & & GDP Lag5 & $0.039(0.084)$ & 0.642 \\
\hline & Tariff Lag6 & $0.227 * *(0.103)$ & 0.028 & & GDP Lag6 & $0.040(0.084)$ & 0.632 \\
\hline & Tariff Lag7 & $-0.351^{* * *}(0.098)$ & 0.000 & & GDP Lag7 & $0.044(0.083)$ & 0.594 \\
\hline & Tariff Lag8 & $0.180 * * *(0.067)$ & 0.008 & & GDP Lag8 & $-0.033(0.076)$ & 0.661 \\
\hline & GDP Lag1 & $-0.045^{*}(0.027)$ & 0.094 & & Tariff Lag1 & $0.177(0.211)$ & 0.402 \\
\hline & GDP Lag2 & $0.007(0.030)$ & 0.807 & & Tariff Lag2 & $-0.215(0.309)$ & 0.487 \\
\hline & GDP Lag3 & $0.063^{* *}(0.030)$ & 0.034 & & Tariff Lag3 & $-0.116(0.292)$ & 0.691 \\
\hline & GDP Lag4 & $-0.017(0.030)$ & 0,570 & & Tariff Lag4 & $-0.250(0.294)$ & 0.397 \\
\hline & GDP Lag5 & $-0.021(0.030)$ & 0.480 & & Tariff Lag5 & $0.473(0.295)$ & 0.111 \\
\hline & GDP Lag6 & $0.006(0.030)$ & 0.831 & & Tariff Lag6 & $-0.036(0.291)$ & 0.903 \\
\hline & GDP Lag7 & $0.001(0.029)$ & 0.976 & & Tariff Lag7 & $-0.182(0.277)$ & 0.513 \\
\hline & GDP Lag8 & $0.012(0.027)$ & 0.650 & & Tariff Lag8 & $0.105(0.190)$ & 0.580 \\
\hline & constant & $0.286(0.489)$ & 0.560 & & constant & $4.658^{* * *}(1.386)$ & 0.001 \\
\hline
\end{tabular}

Notes: Standard errors appear in parentheses next to coefficient estimates. All significant tests are twotailed, ${ }^{*} \mathrm{p} \leqq .10,{ }^{* *} \mathrm{p} \leqq .05,{ }^{* * *} \mathrm{p} \leqq .01$.

Source: own evaluation.

\section{CONCLUSION}

This research empirically examined the causal relationship between tariff levels and economic growth in the US for the period of 1821-2017, by using the Granger causality test. This empirical study differs from other empirical research in that it not only examines a much longer period for US trade policies (1821-2017) but also tackles the causal relations (considering the possibilities of reciprocal causation) between tariff levels and economic growth in the US. The results provide evidence that, for the US, GDP growth unidirectionally causes nominal tariff levels (a short-term effect). Generalizing the results from this research provides empirical evidence that economic growth affects the levels of trade protectionism/liberalization in the US. The results also indicate that there is no empirical evidence of tariff levels affecting GDP growth in the long term or of GDP growth affecting tariff levels in the short or long term. Additionally, the results show that the previous level(s) of tariff protection or GDP growth affect the current levels of tariff protection and GDP growth in the US. 
Identifying the causal relations between trade policies and economic performance in the US, this research also suggests a couple important directions for future research. First, the results for the US case should be generalized by expanding the analyses to other developed countries: the causal relationship between GDP growth (economic development) and tariff levels (i.e., levels of trade protection) in other developed countries. ${ }^{16}$ By doing so, we could see whether the results in this research (GDP growth unidirectionally affecting tariff levels in the short term) are only applicable to the US or could be generalized to other developed countries. ${ }^{17}$ As mentioned before, one important limitation of this task is the difficulty of obtaining nominal tariff data for developed countries (other than the US) for long periods of time; for this, different sources of data (i.e., from both diverse international organizations and agencies in individual governments) might need to be utilized. This research should also be expanded to analyze the causal relationship between trade protectionism/liberalization and economic growth for developing or less developed countries. ${ }^{18}$ Second, additional research will require the utilization of a qualitative research method..$^{19}$ For example, well-planned case studies on trade protectionism and economic growth in the US might need to address when and how the United States' trade policies affect its economic performance and vice versa. When the findings from qualitative analysis are incorporated with those of quantitative analysis in this study, we can be more confident that economic growth affects trade policies in the US. ${ }^{20}$

What are some of this study's policy and theoretical implications? As described above (Previous Research section), relevant theories argue that a state's economic conditions affect its trade policies (economic prosperity to trade liberalization and depression to protectionism). The empirical results of this research provide evidence supporting this theoretical argument, at least for the US, undoubtedly one of the most economically developed states that affects trade policies of other developed and developing countries in the international economic system. Consider the arguments of hegemonic stability theory (Kindleberger, 1973; Gilpin, 1975, 1987; Krasner, 1976; Conybeare, 1984; Keohane, 1984, 1997; Strange, 1987, 1996; Gowa, 1989; Nye, 1990) that, as the economic power and/or will of a hegemon is diminished, public goods of open and stable international economic order become undersupplied and, consequently, the liberal international economic system is weakened (e.g., lessons from histories of the 1920s and '30s as well as the 1970s and '80s). ${ }^{21}$ In this regard, the empirical results of the US economic growth affecting its trade policies (as well as the theoretical argument of hegemonic stability theory) would provide important implications for not only the US itself but also for other states in the international system. In similar coin, recent economic policies of Donald Trump's administration (e.g., America First), such as negating or threatening to negate the TPP (Trans-Pacific Strategic Economic Partnership) and NAFTA (North American Free Trade Agreement), and recent economic conflicts over tariffs (in March/April 2018 and

\footnotetext{
${ }^{16}$ For some of the previous efforts (with time-series and cross-sectional limitations) on this issue (described in previous research section), see, for example, Bairoch (1972, 1976); Caves (1976); Reidel (1977); Verdier (1987); Afontsev (1999); Meadwell (2002).

17 The preliminary analyses in this research provide empirical evidence that, for the period of 1988-2016, GDP growth does not Granger-cause tariff levels, nor do tariff levels Granger-cause GDP growth over the short or long term in the United Kingdom and Spain.

${ }^{18}$ For some previous efforts (with time-series and cross-sectional limitations) on this issue (described in previous research section), see, for example, Lederman (2005); Isakava et al. (2016).

${ }^{19}$ For a qualitative research method, see King et al. (1994); for process-tracing case studies, see Beach \& Pedersen (2013).

${ }^{20}$ For combining quantitative and qualitative methods in international relations, see Lamont (2015).

${ }^{21}$ According to the theory, the international economic system became unstable during the 1920s and '30s (The Great Depression) partly due to the decline of the United Kingdom's economic power and the United States' lack of will to take a leadership role in the system. The theory also posits that the system once again became unstable during 1970s and '80s, this time, when the US economic power had diminished (coupled with the international oil crisis).
} 
continuously) of the US with China (for US agricultural and livestock products as well as Chinesemanufactured steel and aluminum products) and EU (for US agricultural and industrial products and EUmanufactured steel and aluminum products) would provide much more important policy implications for the rest of the world. All in all, the empirical results for US economic conditions and trade policies will suggest important policy and theoretical implications for economic development and trade policies of protectionism/liberalization in other developed and developing states.

\section{REFERENCES}

Acemoglu, D., Johnson, S., \& Robinson, J. A. (2001). The colonial origins of comparative development: an empirical investigation. American Economic Review, 91(5), 1369-1401.

Afontsev, S. A. (1999). Political economy mechanisms of tariff protection in Russia: an empirical study. Economics Education and Research Consortium Working Paper No. 99/16. Economics Education and Research Consortium.

Akaike, H. (1973). Information theory and an extension of the maximum likelihood principle in Petrov, B.N., \& Csaki, F. (eds.) Second international symposium on information theory. Budapest: Akademiai Kiado, 267-281.

Anderson, K., \& Baldwin, R.E. (1986). The political market for tariff protection in industrial countries: new empirical evidence in Odano, S. (ed.) The state of the world economy: essays in honour of Hiroshi Kitamura. London: Macmillan.

Baack, B. D., \& Ray, E. J. (1983). The political economy of tariff policy: a case study of the United States. Explorations in Economic History, 20(1), 73-93.

Bairoch, P. (1972). Free trade and European economic development in the $19^{\text {th }}$ century. European Economic Review, 3(3), 211-245.

Bairoch, P. (1976). Commerce extérieur et développement économique de l'Europe au XiXe siècle. Paris: Mouton.

Bairoch, P. (1989). European trade policy, 1815-1914 in Mathias, P., \& Pollard, S. (eds.) The industrial economies: the development of economic and social policies, the Cambridge economic history of Europe, Vol. VIII. Cambridge: Cambridge University Press, 1-160.

Bairoch, P. (1993). Economics and world history: myths and paradoxes. Chicago: University of Chicago Press.

Baldwin, R.E. (1982). The political economy of protection in Bhagwati, J. N. (ed.) Import competition and response. Chicago: University of Chicago Press, 263-283.

Baldwin, R.E. (1985). The political economy of US import policy. Cambridge: MIT Press.

Batra, R. (1993). The myth of free trade. New York: Scribner's.

Bayward, T.O., \& Elliott, K.A. (1994). Reciprocity and retaliation in U.S. trade policy. Washington, D.C.: Institute for International Economics.

Beach, D., \& Pedersen, R.B. (2013). Process-tracing methods: foundations and guidelines. Ann Arbor: University of Michigan Press.

Ben-David, D. (1993). Equalizing exchange: trade liberalization and income convergence. The Quarterly Journal of Economics, 108(3), 653-679.

Bolt, J., \& van Zanden, J.L. (2014). The Maddison project: collaborative research on historical national accounts. Economic History Review, 67(3), 627-651.

Bolt, J., Inklaar, R., de Jong, H., \& van Zanden, J. (2018). Rebasing 'Maddison': new income comparisons and the shape of longrun economic development. Maddison Project Working Paper No. 10. Retrieved from: https://www.rug.nl/ggdc/html_publications/ memorandum/gd174.pdf (01.01.2018).

Brady, D. W. (1988). Critical elections and congressional policy making. Stanford: Stanford University Press.

Brunner, K., \& Meltzer, A.H. (1979). Three aspects of policy and policymaking: knowledge, data, and institutions. New York: North-Holland Pub. Co.

Capie, F. (1983). Tariff protection and economic performance in the nineteenth century in Black, J., \& Winters, L.A. (eds.) Policy and Performance in International Trade. London: Macmillan, 1-24.

Capie, F. (1994). Tariffs and growth: some insights from the world economy, 1850-1940. Manchester: Manchester University Press.

Cassing, J., McKeown, T.J., \& Ochs, J. (1986). The political economy of the tariff cycle. American Political Science Review, 80(3), 843-862. 
Caves, R.E. (1976). Economic models of political choice: Canada's tariff structure. Canadian Journal of Economics, 9(2), 278-300.

Cheh, J.H. (1974). United States concessions in the Kennedy Round and short-run labor adjustment costs. Journal of International Economics, 4(4), 323-340.

Clemens, M.A., \& Williamson, J.G. (2004). Why did the tariff-growth correlation reverse after 1950? Journal of Economic Growth, 9(1), 5-46.

Constantopoulos, M. (1974). Labour protection in Western Europe. European Economic Review, 5(4), 313-328.

Conybeare, J.A.C. (1983). Tariff protection in developed and developing countries: a cross-sectional and longitudinal analysis. International Organization, 37(3), 441-463.

Conybeare, J.A.C. (1984). Public goods, prisoner's dilemmas and the international political economy. International Studies Quarterly, 28(1), 5-22.

Conybeare, J.A.C. (1991). Voting for protection: an electoral model of tariff policy. International Organization, 45(1), 57-81.

Corden, W.M. (1974). Trade policy and economic welfare. Oxford: Oxford University Press.

Crescenzi, M.J.C., \& Enterline, A.J. (1999). Ripples from the waves? A systemic, time-series analysis of democracy, democratization, and interstate war. Journal of Peace Research, 36(1), 75-94.

Crucini, M.J. (1994). Sources of variation in real tariff rates: The United States, 1900-1940. American Economic Review, 84(3), 732-743.

DeJong, D.N., \& Ripoll, M. (2006). Tariffs and growth: an empirical exploration of contingent relationships. Review of Economics and Statistics, 88(4), 625-640.

Dickey, D.A., \& Fuller, W.A. (1979). Distribution of the estimators for autoregressive time series with a unit root. Journal of the American Statistical Association, 74(366), 427-431.

Dollar, D. (1992). Outward-oriented developing economies really do grow more rapidly: evidence from 95 LDCs, 1976-85. Economic Development and Cultural Change, 40(3), 523-544.

Eckes, A.E. (1995). Opening America's market: U.S. foreign trade policy since 1776. Chapel Hill: University of North Carolina Press.

Edwards, S. (1998). Openness, productivity and growth: what do we really know? Economic Journal, 108(447), $383-398$.

Eichengreen, B. (1989). The political economy of the Smoot-Hawley tariff. Research in Economic History, 12, 1-43.

Engle, R.F., \& Granger, C.W.J. (1987). Co-integration and error correction: representation, estimation, and testing. Econometrica, 55(2), 251-276.

Epstein, D., \& O’Halloran, S. (1996). The partisan paradox and the U.S. tariff, 1877-1934. International Organization, 50(2), 301-324.

Feenstra, R.C., Inklaar, R., \& Timmer, M.P. (2015). The next generation of the Penn world table. American Economic Review, 105(10), 3150-3182.

Freeman, J. R. (1983). Granger causality and the times series analysis of political relationships. American Journal of Political Science, 27(2), 327-358.

Fallows, J.M. (1994). Looking at the sun: the rise of the new East Asian economic and political system. New York: Pantheon Books.

Foreman-Peck, J. (1995). A model of later nineteenth century European economic development. Revista de Historia Económica, 13(3), 441-471.

Frankel, J.A., \& Romer, D.H. (1999). Does trade cause growth? American Economic Review, 89(3), 379-399.

Freeman, J.R., Williams, J.T., \& Lin, T. (1989). Vector autoregression and the study of politics. American Journal of Political Science, 33(4), 842-877.

Gardner, G.W., \& Kimbrough, K.P. (1989). The behavior of U.S. tariff rates. American Economic Review, 79(1), 211218.

Gilpin, R. (1975). U.S. power and the multinational corporation: the political economy of foreign direct investment. New York: Basic Books.

Gilpin, R. (1987). The political economy of international relations. Princeton: Princeton University Press.

Gowa, J. (1989). Rational hegemons, excludable goods, and small groups: an epitaph for hegemonic stability theory? World Politics, 41(3), 307-324. 
Granger, C.W.J. (1969). Investigating causal relations by econometric models and cross-spectral methods. Econometrica, 37(3), 424-438.

Granger, C.W.J. (1980). Testing for causality: a personal viewpoint. Journal of Economic Dynamics and Control, 2(1), 329352.

Grossman, G.M., \& Helpman, E. (1991). Innovation and growth in the global economy. Cambridge: MIT Press.

Gujarati, D.N., \& Poter, D.C. (2009) Basic econometrics. $5^{\text {th }}$ ed. New York: McGraw-Hill Education.

Hansen, W.L. (1990). The international trade commission and the politics of protectionism. American Political Science Review, 84(1), 21-46.

Harrison, A. (1996). Openness and growth: a time series, cross-country analysis for developing countries. Journal of Development Economics, 48, 419-447.

Helleiner, G.K. (1977). The political economy of Canada's tariff structure: an alternative model. Canadian Journal of Economics, 4, 318-326.

Hillman, A.E. (1989). The political economy of protection. New York: Hardwood Academic Publishers.

Hood, M.V., Kidd, Q., \& Morris, I.L. (2008). Two sides of the same coin? employing Granger causality tests in a time series and cross-section framework. Political Analysis, 16(3), 324-344.

Irwin, D.A. (1998). Higher tariffs, lower revenues? Analyzing the fiscal aspects of the "Great Tariff Debate of 1888." The Journal of Economic History, 58(1), 59-72.

Irwin, D.A. (2011). Peddling protectionism: Smoot-Hawley and the Great Depression. Princeton: Princeton University Press.

Isakova, A., Koczan, Z., \& Plekhanov, A. (2016). How much do tariffs matter: evidence from the customs union of Belarus, Kazakhstan, and Russia. Journal of Economic Policy Reform, 19(2), 166-184.

Johansen, S. (1991). Estimation and hypothesis testing of cointegration vectors in Gaussian vector autoregressive models. Econometrica, 59(6), 1551-1580.

Johnston, W., \& Williamson, S. H. (2018). What was the U.S. GDP then? MeasuringWorth. Retrieved from: http://https://www.measuringworth.com/datasets/usgdp/ (01.01.2018).

Keohane, R.O. (1984). After hegemony: cooperation and discord in the world political economy. Princeton: Princeton University Press.

Keohane, R.O. (1997). Problematic lucidity: Stephen Krasner's “state power and the structure of international trade." World Politics, 50(1), 150-170.

Kindleberger, C.P. (1973). The world in depression, 1929-1939. Berkeley: University of California Press.

King, G., Keohane, R.O., \& Verba, S. (1994). Designing social inquiry. Princeton: Princeton University Press.

Krasner, S.D. (1976). State power and the structure of international trade. World Politics, 28(3), 317-347.

Kreuger, A.O. (1974). The political economy of the rent-seeking society. American Economic Review, 64(3), 291-303.

Lamont, C. (2015). Research methods in international relations. London: Sage Publications Ltd.

Lavergne, R.P., \& Shell, K. (1983). The political economy of U.S. tariffs: an empirical analysis. Toronto: Academic Press.

Lederman, D. (2005). The political economy of protection theory and the Chilean experience. Stanford: Stanford University Press.

Lee, J.W. (1993). International trade, distortions, and long-run economic growth. IMF Staff Papers, 40(2), 299-328.

Lucas, R. (1988). On the mechanism of economic development. Journal of Monetary Economics, 22(1), 3-42.

Maddala, G.S. (2001). Introduction to econometrics. $3^{\text {rd }}$ ed. New York: John Wiley \& Sons.

Magee, S., Brock, W.A., \& Young, L. (1989). Black bole tariffs and endogenous policy theory: political economy in general equilibrium. Cambridge: Cambridge University Press.

Maizels, A. (1963). Industrial growth and world trade. Cambridge: Cambridge University Press.

Mansfield, E.D., \& Busch, M.L. (1995). The political economy of nontariff barriers. International Organization, 49(4), 723-749.

Marvel, H.P., \& Ray, E.J. (1983). The Kennedy Round: evidence on the regulation of international trade in the United States. American Economic Review, 73(1), 190-197.

Matsuyama, K. (1992). Agricultural productivity, comparative advantage, and economic growth. Journal of Economic Theory, 58(2), 317-334.

Mayer, W. (1984). Endogenous tariff formation. American Economic Review, 74(5), 970-985. 
McKeown, T.J. (1984). Firms and tariff regime change: explaining the demand for protection. World Politics, 36(2), 215-233.

Meadwell, H. (2002). The political economy of tariffs in late nineteenth-century Europe: reconsidering republican France. Theory and Society, 31(5), 623-651.

Nelson, D. (1988). Endogenous tariff theory: a critical survey. American Journal of Political Science, 32(3), $796-837$.

Newey, W.K., \& West, K.D. (1994). Automatic lag selection in covariance matrix estimation. Review of Economic Studies, 61(4), 631-653.

Nye, J.S. (1990). Bound to lead: the changing nature of American power. New York: Basic Books.

O'Rourke, K.H. (2000). Tariffs and growth in the late 19 th century. Economic Journal, 110(463), 456-483.

Olarreaga, M., \& Soloaga, I. (1998) Endogenous tariff formation: the case of MERCOSUR. World Bank Economic Review, 12(2), 297-320.

Olson, M. (1982). The rise and decline of nations. New Haven: Yale University Press.

Pesaran, M.H., \& Shin, Y. (1998). An autoregressive distributed-lag modeling approach to cointegration analysis in Strøm, S. (ed.) Econometrics and economic theory in the 20 th century. Cambridge: Cambridge University Press, 371413.

Pesaran, M.H., Shin, Y., \& Smith, R.J. (2001). Bounds testing approaches to the analysis of level relationships. Journal of Applied Econometrics, 16(3), 289-326.

Phillips, R.F. (1991). A constrained maximum likelihood approach to estimating switching regressions. Journal of Econometrics, 48(1-2), 241-262.

Phillips, P.C.B., \& Hansen, B.E. (1990). Statistical inference in instrumental variables regression with I(1) processes. Review of Economic Studies, 57(1), 99-125.

Phillips, P.C.B., \& Loretan, M. (1991). Estimating long-run economic equilibria. Review of Economic Studies, 58 (3), $407-$ 436.

Phillips, P.C.B., \& Perron, P. (1988). Testing for a unit root in time series regression. Biometrika, 75(2), 335-346.

Pincus, J.J. (1975). Pressure groups and the pattern of tariffs. Journal of Political Economy, 83(4), 757-778.

Raftery, A.E. (1995). Bayesian model selection in social research. Sociological Methodology 25, 111-163.

Ray, E.J. (1974). The optimum commodity tariff and tariff rates in developed and less developed countries. Review of Economics and Statistics, 56(3), 369-377.

Ray, E.J. (1981a). Tariff and nontariff barriers in the United States and abroad. The Review of Economics and Statistics, 63(2), 161-168.

Ray, E.J. (1981b). The determinants of tariff and nontariff trade restrictions in the United States. Journal of Political Economy, 89(1), 105-121.

Riedel, J. (1977). Tariff concessions in the Kennedy Round and the structure of protection in West Germany. Journal of International Economics, 7(2), 133-143.

Rivera-Batiz, L. A., \& Romer, P. M. (1991). Economic integration and endogenous growth. Quarterly Journal of Economics, 106(2), 531-555.

Rodríguez, F., \& Rodrik, D. (2000). Trade policy and economic growth: a skeptic's guide to the cross-national evidence in Bernanke, B. \& Rogoff, K. (eds.) NBER macroeconomics annual 2000. Cambridge: National Bureau of Economic Research, 261-338.

Rosenberg, H. (1967). Grosse Depression und Bismarckzeit: Wirtschaftsablauf, Gesellschaft und Politik in Mitteleuropa. Berlin: Walter de Gruyter.

Sachs, J.D., \& Warner, A. (1995). Economic reform and the process of global integration. Brookings Papers on Economic Activity, 26(1), 1-118.

Schularick, M., \& Solomou, S. (2011). Tariffs and economic growth in the first era of globalization. Journal of Economic Growth, 16(1), 33-70.

Schwarz, G. (1978). Estimating the dimension of a model. The Annals of Statistics, 6(2), 461-464.

Sims, C.A. (1980a). Macroeconomics and reality. Econometrica, 48(1), 1-48.

Sims, C.A. (1980b). Comparison of interwar and postwar business cycles: monetarism reconsidered. American Economic Review, 70(2), 250-257.

Stanwood, E. (1903). American tariff controversies in the nineteenth century. New York: Russell and Russell. 
Stern, R.M. (1964). The U.S. tariff and the efficiency of the U.S. economy. American Economic Review, 54(3), 459-470.

Stewart, C. (1991). Lessons from the post-Civil War era in Cox G. W., \& Kernel, S. (eds.) The politics of divided government. Boulder: Westview Press, 203-238.

Stokey, N.L. (1991). Human capital, product quality, and growth. Quarterly Journal of Economics, 106(2), 587-616.

Strange, S. (1979). The management of surplus capacity: or how does theory stand up to protectionism 1970s style?" International Organization, 33(3), 303-334.

Strange, S. (1987). The present myth of lost hegemony. International Organization, 41(4), 551-574.

Strange, S. (1996). The retreat of the state: the diffusion of power in the world economy. New York: Cambridge University Press.

Taussig, F.W. (1931). The tariff history of the United States. New York: Augustus M. Kelley.

Taylor, A.M. (1998). On the costs of inward-looking development: price distortions, growth, and divergence in Latin America. Journal of Economic History, 58(1), 1-28.

Thompson, R.W. (1888). The history of protective tariff laws. New York: Garland Publishing.

Thompson, W.R., \& Reuveny, R. (1998). Tariffs and trade fluctuations: does protectionism matter as much as we think? International Organization, 52(2), 421-440.

Trefler, D. (1993). Trade liberalization and the theory of endogenous protection: an econometric study of US import policy. Journal of Political Economy, 101(1), 138-160.

United Nations Conference on Trade and Development. (2018). Trade analysis information system database. Geneva: United Nations Conference on Trade and Development. Retrieved from http://unctad.org/en/Pages/DITC/Trade-Analysis/Non-Tariff-Measures/NTMs-trains.aspx (01.01.2018).

U.S. Census Bureau. (Diverse years). Historical statistics of the United States. Washington, D.C.: U.S. Census Bureau.

U.S. Census Bureau. (Diverse years). Statistical abstract of the United States. Washington, D.C.: U.S. Census Bureau.

U.S. International Trade Commission. (2018). USITC tariff database. Washington, D.C.: U.S. International Trade Commission. Retrieved from https://dataweb.usitc.gov/ scripts/tariff.asp (01.01.2018).

Vamvakidis, A. (2002). How robust is the growth-openness connection? historical evidence. Journal of Economic Growth, 7(1), 57-80.

Verdier, D.D. (1987). Making trade policy in France and United States, 1860-1986. Doctoral thesis. Berkley: University of California.

Wacziarg, R. (2001). Measuring the dynamic gains from trade. World Bank Economic Review, 15(3), 393-429.

Wacziarg, R., \& Welch, K.H. (2008). Trade liberalization and growth: new evidence. World Bank Economic Review, 22(2), 187-231

Wiener, N. (1956). The theory of prediction in Beckenbach, E. F. (ed.) Modern mathematics for engineers. New York: McGraw Hill, 165-190.

World Bank. (Diverse years). World development indicators. Washington, D.C.: World Bank Group.

World Trade Organization. (2018). Trade and tariff database. Geneva: World Trade Organization. Retrieved from: https://www.wto.org/english/res_e/statis_e/ statis_e.htm (01.01.2018).

Yanikkaya, H. (2003). Trade openness and economic growth: a cross-country empirical investigation. Journal of Development Economics, 72(1), 57-89.

Young, A. (1991). Learning by doing and the dynamic effects of international trade. The Quarterly Journal of Economics, 106(2), 369-405.

Zellner, A. (1979). Causality and econometrics. Carnegie-Rochester Conference Series on Public Policy, 10(1), 9-54. 